\title{
SMART USE OF ORGANIC AND BIO-FERTILIZERS TO IMPROVE PHYSICAL PROPERTIES OF SANDY SOIL AND ITS PRODUCTIVITY, OF FABA BEAN AND MAIZE
}

\author{
S.F. Mansour, A.A.M Ragab, E. G. Abo-Elela and E.F. Ramadan \\ Soils, Water and Environ. Res. Inst., Agric. Res. Centre, Giza, Egypt.
}

Received: Jan. 17, 2017

Accepted: Feb. 22,2017

\begin{abstract}
The major goal of this study was to evaluate the impact of organic fertilizer (i.e town refuse, biogas and FYM) combined with bio-fertilizer (effective microorganism [EM] and the $\mathrm{N}_{2}$ fixer Compomax [CoM] on improveing some physical and chemical properties of sandy soil as well as productivity of faba bean -maize cropping rotation, an alternative cropping system under sprinkler irrigation system. Two field experiment were conducted at the experimental Farm of the Agricultural Research Station, EL-Ismailia Governorate, Agric. Res. Centre (ARC), Egypt, during two winter seasons 2014/2015 and 2015/2016 and two summer seasons 2015 and 2016. A split plot design with three replicates was employed applied treatments, included control mineral fertilizer (recommended dose of $N, P$ \& K) (Conventional Agricultural) , organic fertilizer town refuse; biogas manure and farmyard manure [FYM] each applied alone andlor combined with bio-fertilizers i.e EM and the $\mathrm{N}_{2}$ fixer Compomax [CoM] . The obtained results can be summarized as follows:

Application of Biogas manure combined with EM recorded the highest yield parameters followed by FYM application and the lowest one was recorded with that received town refuse, likewise the highest available of NPK. Similar trend of available of NPK was also observed with the residual crop (maize).

Application of the tested organic fertilizer improved the physical and chemical properties of used soil,[ increasing total porosity (T.P), fine capillary pores (FCP), soil moisture contents at field capacity (F.C), wilting point (W.P), available water (A.W). ECe, O.M, and available N, $P$ and K. On the contrary, $\mathrm{pH}$, bulk density (B.D), hydraulic conductivity (H.C)], as compared with the control.
\end{abstract}

Key words: Available N, P and K , bio fertilizer, chemical properties, faba bean, maize , mineral nitrogen, organic fertilizer, physical properties, sandy soil .

\section{INTRODUCTION}

Nowadays inorganic fertilizers became increasingly more expensive due to increase in price of fertilizers day by day. Moreover, today the agriculture is now facing a challenge of over dependence on synthetic inputs and day by day it change in price of these inputs. The occurrence of multinutrient deficiencies and overall decline in the productive capacity of the soil due to nonjudicious fertilizer use, have been widely reported.

The use of inorganic fertilizers alone has not been helpful under intensive agriculture because it aggravates soil degradation
(Sharma and Mittra, 1991). Prabu and Uthaya (2006) concluded that organic manures play a vital role in maintaining physical, chemical and biological conditions of soil and supply macro and micronutrients to crops besides maintaining humic substances in soil and also the wastes are effectively utilized for crop production. Addition of organic sources could increase corn yields through increaseing soil productivity and higher fertilizer use efficiency. Farmyard manure is a potentially important source of nitrogen $(\mathrm{N})$, phosphorus $(\mathrm{P})$ and potassium $(\mathrm{K})$. (Khosro and yousef, 2012). 
Bio-fertilizers are microbial preparations containing living cells of different microorganisms which have the ability to mobilize plant nutrients in soil from unusable to usable form. They are environmentally friendly, play a significant role in the crop production, help to build up the lost microflora and improve the soil health Mosa, et al (2015) Application of combined organic manures and effective microorganisms was positively affected growth and yield of wheat plant (Youssef, 2011). Fertilizer applications could affect soil physical properties directly or indirectly such as aggregate stability, water holding capacity, porosity, infiltration rate, hydraulic conductivity and bulk density due to increases in soil organic matter (SOM) and soil organic carbon (SOC )content (Haynes and Naidu 1998). Beneficial effects of increasing SOM concentration on enhancing soil structural stability have been widely documented (Barzegar, et al 1997). The balanced fertilization (Rational fertilization) is the proper supply of all macronutrients and micronutrients in a balanced ratio throughout the growth of crops based on the results of soil test. According to the description of $4 R$ by International Plant nutrition Institute (IPNI) (Jensen, et al., 2015) are:

1) Apply the "Right Rate" of fertilizer to match nutrient supply with crop requirements; 2) Apply fertilizer at the "Right Time" so nutrients will be available when crop demand is high; 3) Apply fertilizer in the "Right Place" or location where the crop can access the nutrients most effectively; 4) Use the "Right Form" of fertilizers that are in or are easily converted over to compounds best used by the target crop.

It is important to note that increases in SOM and other favorable soil quality characteristics change slowly over time with organic management (Gomiero et al., 2011). (Pandey et al., 2011) found that compost increased plant growth by supply nutrients to the plants through mineralization and improvement in physic-chemical properties of the soil. Based on the production process, fertilizers can be roughly categorized into three types, chemical, organic and biofertilizers. Each type of fertilizer has its advantages and disadvantages. These advantages need to be integrated in order to achieve optimum performance by each type of fertilizer and to realize balanced nutrient management for crop growth (Chen, et al., 2006). Khafagy, et al,. 2015 concluded that using organic fertilizer with suitable quantity were the pest for amelioration and, improved soil properties i.e. increased hydraulic conductivity (Ks), organic matter (O.M) and grain yield. On the contrary, bulk density, Penetration resistance (P.R.), $\mathrm{pH}$ values were decreased. Furthermore,soil structure was improved, also, the growth traits i.e. Plant height, dry weight, grain yield, stover yield.

The main objective of this study is to evaluate the effect of organic fertilizer i;e FYM, biogas and town refuse combined with bio-fertilizer i.e (effective microorganism [EM] and the $\mathrm{N}_{2}$-fixers Compomax [CoM] on improving some physical and chemical properties of sandy soil, as well as increase its productivity under faba bean-maize cropping rotation.

\section{MATERIALS AND METHODS}

A field experiment was carried out at experimental Farm of the Agricultural Research Station, EL-Ismailia Governorate, Agric. Res. Centre (ARC), Egypt, during two winter seasons 2014/2015 and 2015/2016 and as well as summer seasons 2015 and 2016, which were conducted in an alternative cropping system under sprinkler irrigation system to study the effect of organic fertilizers in combination with biofertilizers on the production of faba bean (Vica faba L.) variety balady as the main crop and maize (Zea maize L.) variety fardy 10 as the following crop. Some physical and chemical properties of the investigated soil and irrigation water were determined according to (Rebecca, 2004) and shown in Table (1).

Also, the composition of manure used in the experiment is presented in Table (2). 
Table 1: Chemical characteristics of the studied soil $(0-30 \mathrm{~cm})$ and irrigation water.

\begin{tabular}{|c|c|c|c|c|c|c|c|c|c|c|c|}
\hline \multirow[t]{2}{*}{ Sample } & \multirow{2}{*}{$\begin{array}{c}\mathrm{EC} \\
\mathrm{dS} / \mathrm{m}\end{array}$} & \multirow[t]{2}{*}{ pH } & \multicolumn{8}{|c|}{ Soluble ions (meq/l) } & \multirow[t]{2}{*}{ SAR } \\
\hline & & & $\mathrm{Ca}++$ & Mg++ & $\mathrm{Na}+$ & $\mathrm{K}+$ & $\mathrm{CO} 3=$ & HCO3- & Cl- & SO4= & \\
\hline Soil & 0.36 & 7.64 & 1.61 & 0.82 & 1.02 & 0.18 & -- & 0.93 & 0.96 & 1.74 & 0.85 \\
\hline Water & 0.45 & 7.91 & 1.24 & 1.76 & 1.29 & 0.14 & - & 0.52 & 1.92 & 1.99 & 1.06 \\
\hline \multicolumn{12}{|c|}{ Some physical characteristics of the studied soil $(0-30 \mathrm{~cm})$. } \\
\hline \multicolumn{9}{|c|}{ Particle size distribution \% } & \multirow{2}{*}{\multicolumn{2}{|c|}{$\begin{array}{l}\text { Organic } \\
\text { matter \% }\end{array}$}} & \multirow{2}{*}{$\begin{array}{c}\mathrm{CaCO} 3 \\
\%\end{array}$} \\
\hline \multicolumn{3}{|c|}{ Coarse sand } & \multicolumn{2}{|c|}{ Fine sand } & Silt & Clay & \multicolumn{2}{|c|}{$\begin{array}{c}\text { Texture } \\
\text { class }\end{array}$} & & & \\
\hline \multicolumn{3}{|c|}{31.82} & \multicolumn{2}{|c|}{61.61} & 1.22 & 5.35 & \multicolumn{2}{|c|}{ Sandy } & \multicolumn{2}{|c|}{0.44} & 1.42 \\
\hline
\end{tabular}

Table 2: Chemical composition of organic manures used in field experiments

\begin{tabular}{|c|c|c|c|c|c|c|c|}
\hline Paremetres & $\begin{array}{l}\text { Town } \\
\text { refuse }\end{array}$ & $\begin{array}{c}\text { Biogas } \\
\text { manure }\end{array}$ & $\begin{array}{c}\text { Farmyard } \\
\text { manure }\end{array}$ & Analysis & $\begin{array}{l}\text { Town } \\
\text { refuse }\end{array}$ & \begin{tabular}{c|} 
Biogas \\
manure
\end{tabular} & $\begin{array}{c}\text { Farmyard } \\
\text { manure }\end{array}$ \\
\hline Moisture (\%) & 20.00 & 24.20 & 26.10 & Total Carbon\% & 23.5 & 41.14 & 36.13 \\
\hline Density $(\mathrm{g} / \mathrm{cm} 3)$ & 0.68 & 0.32 & 0.21 & C/N Ratio & 29.7 & 21.3 & 23.9 \\
\hline $\mathrm{pH}(1: 10)$ & 7.88 & 7.18 & 7.24 & Available $p \%$ & 0.24 & 0.25 & 0.36 \\
\hline EC $(1: 10)$ & 1.87 & 1.98 & 2.12 & Available K \% & 1.15 & 2.18 & 1.78 \\
\hline N-NH4 (ppm) & 38.00 & 63.00 & 52.00 & DTPA-Fe (ppm) & 1346 & 1580 & 1760 \\
\hline $\mathrm{N}-\mathrm{NO} 3$ (ppm) & 12.00 & 29.00 & 38.00 & DTPA-Mn (ppm) & 239 & 0.82 & 0.75 \\
\hline Total Nitrogen \% & 0.79 & 1.93 & 1.51 & DTPA-Zn (ppm) & 250 & 6.84 & 5.75 \\
\hline Total phosphorus \% & 0.46 & 0.41 & 0.54 & O.M. & 15.8 & 38.6 & 30.2 \\
\hline Total potassium \% & 0.83 & 1.61 & 1.22 & & & & \\
\hline
\end{tabular}

The experimental treatments were in a split plot design with three replicates. The soil was carefully prepared and divided into of 12 plots $(3 \times 3.5 \mathrm{~m})$, an area of $10.5 \mathrm{~m}^{2}$ $(1 / 400 \mathrm{fed})$. The mineral nitrogen fertilizer applied in the form of ammonium nitrate $(33.5 \% \mathrm{~N})$ at the rate of 20 and $90 \mathrm{~kg} \mathrm{fed}^{-1}$ for both faba bean and maize, respectively. in two equal doses, the first was before planting and the second was at the tillering stage 40 days after sowing. The organic fertilizers applied at the rate $20 \mathrm{~m}^{3} \mathrm{fed}^{-1}$. during the soil preparation before planting. All plots were received phosphorus and potassium applied at relative rates of $150 \mathrm{Kg}$ $\mathrm{P}_{2} \mathrm{O}_{5}$ fed $^{-1}$ and $50 \mathrm{Kg} \mathrm{K}_{2} \mathrm{O}$ fed ${ }^{-1}$ in the form of single super phosphate $\left(15 \% \mathrm{P}_{2} \mathrm{O}_{5}\right)$ and potassium sulphate $\left(\begin{array}{lll}48 & \% & \mathrm{~K}_{2} \mathrm{O}\end{array}\right)$, respectively. Phosphorus applied basically during soil preparation, while potassium applied after 30 days from planting. Effective microorganism (EM) and Compomax $\mathrm{N}_{2}$ fixer (CoM) sprayed twice at a rate of 4 Liter fed $^{-1}$, once every month starting from planting. The following treatments were applied :

\section{A: Main plots [ organic fertilizers ]. \\ 1- without organic fertilizer ( Control) (recommended dose of N, P \& K) \\ 2- applied organic fertilizer (Town refuse; Biogas manure and Farmyard manure )}

\section{B: Sub main plots [bio-fertilizers] (foliar spray).}

1- without 2- effective microorganism [EM].

3- N2 fixer Compomax [CoM]

The main microbial species included in EM prepared according to Kato et al. (1999) The chemical and microbial analyses of $\mathrm{N}_{2}-$ fixers (Compomax) and EM are given in Table 3. 
Mansour, et al.,

Table (3): Composition of biofertilizer used in field experiments

\begin{tabular}{|l|l|l|l|}
\hline \multicolumn{2}{|l|}{ Effective micro-organisms (EM) composition } & \multicolumn{2}{l|}{ Compomax N-fixers (CoM) composition } \\
\hline Bacteria: & Yeasts: & Azotobacter choroccum & Total $\mathrm{N}: 3.5 \%$ \\
Lactobacillus plantarum & Saccharomyces cerevisiae & Azospirillum lipoferm & $\mathrm{P}_{2} \mathrm{O}_{5}: 2.5 \%$ \\
Lactobacillus casei & Actiomycetes: & Bacillus polymexa & $\mathrm{K}_{2} \mathrm{O}: 0.4$ \\
Streptococcus lactis & Streptomyces albus & & $\mathrm{Zn:} 14 \mathrm{ppm}$ \\
Rhodopseudomonas palustris & Streptomyces griseus & & $\mathrm{Fe:} 18 \mathrm{ppm}$ \\
Radobacter sphaeraides & Fungi: Aspergillus oryze & & $\mathrm{Mn}: 10 \mathrm{ppm}$ \\
\hline
\end{tabular}

Observation on yield components of faba bean and maize were recorded in five randomly selected plants from each ber plot. Seeds and foliage of faba bean and grain and Stover yields of maize were recorded after complete sun drying from each net plot. Then, samples of faba bean and maize were oven ground and digested for the determination of NPK contents. Disturbed and undisturbed soil samples were taken from $0-20 \mathrm{~cm}$. depth and prepared to determine physical and chemical properties according to the standard methods described in Table (4).

\section{RESULTS AND DISCUSSION Available $N, P \& K$ in soil of Faba bean}

Soil available N, P \& K in Table (5), appeared that application of biogas manure signifidintly increased by double-fold compared to the control received without organic manure. Likewise this application signifidintly surpassed the other treatments of organic fertilizers. This could be due to the enhancing effect of organic fertilizer on vegetative growth and root growth, which release hydrogen ions, phenolic compounds and organic acids as well as acidification effect of manure applied that help in increasing nutrients availability and uptake of $\mathrm{N}, \mathrm{P} \& \mathrm{~K}$ by faba bean plants. Tiwari et al. (2002) have also reported that the inclusion of manure in the fertilization schedule improved the organic carbon status and available $\mathrm{N}, \mathrm{P}, \mathrm{K}$ and $\mathrm{S}$ in soil, sustaining soil health. Addition of organic materials of various origins to soil has been one of the most common practices to improve soil physical properties (Celik et al., 2004).

\section{Available N, P \& $K$ in soil of Maize}

The residual effect of applied manure increased significantly the available N, P \& K in soil of maize (Table 5). However, the organic fertilizers, biogas manure treatment recorded the highest values of soil for available N, P \& K, respectively, followed by those recorded by FYM. While, the lowest soil available $N, P$ \& $K$ values recorded with town refuse for available $\mathrm{N}, \mathrm{P} \& \mathrm{~K}$, respectively. This trend could be explained by the role of biogas manure as natural chelating agent resulted in increasing N, P \& $\mathrm{K}$ availability in soil. Bio-fertilizers are important components for the integrated nutrients management. These potential biological fertilizers would play a key role in productivity and sustainability of soil and also act as environmentally eco-friendly and cost effective inputs for the marginal farmers. Biofertilizers are products containing living cells of different types of microorganisms, which when, applied to seeds, plant surface or soil, colonize the rhizosphere or the interior of the plant and promote growth by converting nutritionally important elements (nitrogen, phosphorus) from unavailable to available form through biological process such as nitrogen fixation and solubilization of rock phosphate (Rokhzadi et al., 2008) 
Table (4): Soil properties and plant as determined by the standard methods described by the different publishers.

\begin{tabular}{|l|l|}
\hline \multicolumn{1}{|c|}{ Soil properties } & \multicolumn{1}{|c|}{ References } \\
\hline Chemical analysis & Cottenie et al., 1982 \\
\hline Particle size distribution (\%) $\quad\left(\mathrm{Mg} \mathrm{m}^{-3}\right)$ & Gee and Bauder, 1986 \\
\hline Bulk density $\quad$ Vomocil, 1965 \\
\hline - Saturated hydraulic conductivity. & Klute and Dirksen (1986) \\
\hline - Pore size distribution & De Leenheer and De Boodt (1965) \\
\hline - Available nutrients & Rebecca (2004), \\
\hline - statistical analysis & Snedecor and Cochran (1989), \\
\hline - soil reaction (pH), EC $\left(\mathrm{dS} \mathrm{m}^{-1}\right)$ Organic matter content (\%). & Page et al., (1982) \\
\hline - Soluble cations (m.mol L $\left.{ }^{-1}\right)$ & \\
\hline
\end{tabular}

Table 5: Effect of organic fertilizer and biofertilzer on available nutrients $N, P$ and $K$ in sandy soil in the first and secand year

\begin{tabular}{|c|c|c|c|c|c|c|c|c|c|c|c|c|}
\hline \multirow{3}{*}{ Organic fertilizer } & \multicolumn{12}{|c|}{$1^{\text {st }}$ year } \\
\hline & \multicolumn{4}{|c|}{$\begin{array}{c}\text { Available } \mathrm{N}\left(\mathrm{kg} \mathrm{fed}^{-1}\right) \text { faba bean } \\
\text { soil }\end{array}$} & \multicolumn{4}{|c|}{$\begin{array}{c}\text { Available } P\left(\mathrm{~kg} \mathrm{fed}^{-1}\right) \text { faba } \\
\text { bean soil }\end{array}$} & \multicolumn{4}{|c|}{$\begin{array}{c}\text { Available } \mathrm{K}\left(\mathrm{kg} \mathrm{fed}^{-1}\right) \text { faba } \\
\text { bean soil }\end{array}$} \\
\hline & Without & EM & CoM & Mean & Without & EM & CoM & Mean & Without & EM & CoM & Mean \\
\hline Cont. (Without) & 9.31 & 17.32 & 16.11 & 14.25 & 5.44 & 8.37 & 5.24 & 6.35 & 40.22 & 67.1 & 60.2 & 55.85 \\
\hline Town refuse & 14.47 & 24.97 & 21.23 & 20.22 & 8.81 & 19.2 & 14.74 & 14.26 & 69.94 & 105 & 90.4 & 88.44 \\
\hline Biogas manure & 20.93 & 45.33 & 22.63 & 29.63 & 13.35 & 21.6 & 16.57 & 17.19 & 83.20 & 120 & 98.8 & 100.76 \\
\hline Farmyard manure & 18.90 & 40.83 & 21.70 & 27.14 & 11.74 & 20.2 & 16.14 & 16.01 & 75.01 & 113.5 & 93.6 & 94.03 \\
\hline Mean & 16.15 & 22.93 & 20.42 & & 9.84 & 17.4 & 13.17 & & 62.51 & 24.42 & 85.7 & \\
\hline \multirow{2}{*}{ LSD (5 \%) } & \multicolumn{2}{|l|}{$\begin{array}{l}\text { Organic } \\
\text { Biofertilzer }\end{array}$} & 3.29 & & \multicolumn{3}{|c|}{1.40} & 1.25 & \multicolumn{4}{|c|}{2.83} \\
\hline & \multicolumn{2}{|l|}{ Interaction } & \multicolumn{2}{|l|}{5.39} & \multicolumn{4}{|c|}{ NS } & \multicolumn{4}{|c|}{2.73} \\
\hline \multirow{3}{*}{ Organic fertilizer } & \multicolumn{12}{|c|}{$2^{\text {nd }}$ year } \\
\hline & \multicolumn{4}{|c|}{$\begin{array}{c}\text { Available } \mathrm{N}\left(\mathrm{kg} \mathrm{fed}^{-1}\right) \text { in maize } \\
\text { soil }\end{array}$} & \multicolumn{4}{|c|}{$\begin{array}{c}\text { Available } \mathrm{P}\left(\mathrm{kg} \mathrm{fed}^{-1}\right) \text { in } \\
\text { maize soil }\end{array}$} & \multicolumn{4}{|c|}{$\begin{array}{c}\text { Available } \mathrm{K}\left(\mathrm{kg} \mathrm{fed}^{-1}\right) \text { in maize } \\
\text { soil }\end{array}$} \\
\hline & Without & EM & CoM & Mean & Without & EM & CoM & Mean & Without & EM & CoM & Mean \\
\hline Cont. (Without) & 6.43 & 10.25 & 9.86 & 8.85 & 3.73 & 6.82 & 5.33 & 5.29 & 12.12 & 16.55 & 14.06 & 14.24 \\
\hline Town refuse & 13.33 & 20.00 & 17.33 & 16.89 & 5.44 & 11.0 & 8.28 & 8.24 & 24.35 & 34.48 & 31.49 & 30.11 \\
\hline Biogas manure & 16.70 & 24.50 & 18.30 & 19.83 & 7.18 & 13.6 & 10.32 & 10.38 & 28.62 & 87.75 & 33.16 & 49.84 \\
\hline Farmyard manure & 14.67 & 22.00 & 17.67 & 18.11 & 6.49 & 12.2 & 9.18 & 9.27 & 26.99 & 39.00 & 32.49 & 32.83 \\
\hline Mean & 12.78 & 19.19 & 15.72 & & 5.71 & 10.9 & 8.28 & & 23.02 & 44.45 & 27.8 & \\
\hline \multirow{2}{*}{ LSD (5 \%) } & \multicolumn{2}{|l|}{$\begin{array}{c}\text { Organic } \\
\text { Biofertilzer }\end{array}$} & $\begin{array}{l}0.15 \\
0.45\end{array}$ & & & $\begin{array}{l}0 . \\
0.3\end{array}$ & $\begin{array}{l}12 \\
37\end{array}$ & & & $\begin{array}{l}0.5 \\
0.6\end{array}$ & & \\
\hline & \multicolumn{2}{|l|}{ Interaction } & \multicolumn{2}{|l|}{0.74} & & $\mathrm{~N}$ & IS & & & 1.0 & 5 & \\
\hline
\end{tabular}

Without: no biofertilizer, EM: Effective microorganism, CoM: $\mathrm{N}$ fixer Compo max 


\section{Effect of applied organic fertilizer} and bio-fertilizeron soil properties. 1) Soil chemical properties:

\section{a.) Soil salinity $\left(\mathrm{EC}_{\mathrm{e}}\right)$ :}

The movement of soluble salts in the soil depends mainly on its texture, structure, total porosity and hydraulic conductivity. Data in Table (6) indicated that the mean values of soil Ece after the first year increase percent were 75,136 and $206 \%$ for Town refuse, Biogas manure and Farmyard manure, compared to the control, respectively. while the mean values of soil $\mathrm{Ec}_{\mathrm{e}}$ after the second year increase percent were 26,70 and $119 \%$ for Town refuse, Biogas manure and Farmyard manure, compared to the control, respectively. Moreover, the same trend was observed with bio-fertilizer in both seasons. Farmyard manure application was the most effective in increasing soil salinity compared to other manure and untreated soil. Effect of organic fertilizers application for their influences on increasing soil salinity can be arranged in the descending order as follows:, Farmyard manure $>$ Biogas manure $>$ Town refuse $>$ Cont.

This could be attributed to, the salinity of the applied organic fertilizers and coming salts from irrigation water and inhibit the salts from leaching from the soil. Similar result were obtained by Bevacqua and Mellano (1994) who reported that municipal compost cause a salinity problems that could threaten the production of sensitive crops.

\section{b) Soil PH:}

Data in Table (6) obtained after the first year showed that $\mathrm{pH}$ decreased from 7.64 to 7.34 at addition Biogas manure. Moreover, the same trend was observed after the second year and bio-fertilizer in both seasons. Biogas manure application was the most effective in decreasing soil $\mathrm{pH}$ compared to others and that the effect of added fertilizer could be arranged in the ascending order as follows: Biogas manure $<$ Farmyard manure < Town refuse < Cont. These results are in agreement with Mokolobate and Haynes (2002) who found that additions of organic manure decreased the $\mathrm{pH}$ in the soil, this could be attributed to that may be ascribed to the release of organic acids as a vesu $\mathrm{H}$ of added organic fertilizer decomposition, consequently, release of $\mathrm{H}$ ions in soil solution.

Table (6): Effect of organic fertilizer and biofertilzer on some chemical properties in sandy soil in the first and secand year.

\begin{tabular}{|l|c|c|c|c|c|c|c|c|c|}
\hline \multirow{2}{*}{ Organic fertilizer } & \multicolumn{9}{|c|}{$1^{\text {st }}$ year } \\
\cline { 2 - 12 } & \multicolumn{3}{|c|}{ Without } & \multicolumn{3}{c|}{ EM } & \multicolumn{3}{c|}{ pomax N-fixers (CoM) } \\
\cline { 2 - 12 } & pH & Ec & $\mathbf{O . M}$ & pH & Ec & O.M. & pH & Ec & O.M. \\
\hline Cont.(without) & 7.64 & 0.36 & 0.44 & 7.63 & 0.36 & 0.45 & 7.64 & 0.36 & 0.46 \\
\hline Town refuse & 7.55 & 0.63 & 0.48 & 7.56 & 0.64 & 0.49 & 7.55 & 0.64 & 0.49 \\
\hline Biogas manure & 7.34 & 0.85 & 0.63 & 7.36 & 0.87 & 0.65 & 7.37 & 0.88 & 0.65 \\
\hline Farmyard manure & 7.45 & 1.10 & 0.54 & 7.44 & 1.08 & 0.55 & 7.44 & 1.07 & 0.55 \\
\hline \multicolumn{10}{|c|}{$\mathbf{2}^{\text {nd }}$ year } \\
\hline Cont.(without) & 7.61 & 0.43 & 0.31 & 7.58 & 0.44 & 0.33 & 7.59 & 0.45 & 0.33 \\
\hline Town refuse & 7.45 & 0.54 & 0.38 & 7.43 & 0.55 & 0.39 & 7.44 & 0.56 & 0.39 \\
\hline Biogas manure & 7.24 & 0.73 & 0.48 & 7.25 & 0.72 & 0.49 & 7.24 & 0.73 & 0.49 \\
\hline Farmyard manure & 7.33 & 0.94 & 0.42 & 7.34 & 0.95 & 0.43 & 7.34 & 0.96 & 0.44 \\
\hline
\end{tabular}

Without: no biofertilizer, EM: Effective microorganism, CoM: $\mathrm{N}$ fixer Compo max 


\section{c) Organic matter (O.M.) :}

Data in Table (6) indicated that application of any organic fertilizers, slightly increased soil organic matter content. Biogas manure application was the most effective in increasing soil organic matter content, compared to other manure and untreated soil. Effect of organic fertilizers application for their influences on increasing soil organic matter content can be arranged in the descending order as follows:, Biogas manure $>$ Farmyard manure $>$ Town refuse $>$ Cont.. Similar trend was found throughout second season. This could be attributed to the added organic matter into the soil through application. These results are in agreement with those by McConnell et al. (1993) reported that compost applied at rates varying from 18 to $146 \mathrm{t} \mathrm{ha}^{-1}$ produced a 6 to $163 \%$ increase in soil organic matter. As well as Zebarth et al. (1999) over a threeyear period showed increases in soil organic matter from 5 different organic sources.

\section{2) Soil physical properties: \\ a) Soil bulk density}

Soil bulk density is the main soil character that must be taken into consideration when improving soil physical properties. Bulk density was mostly affected by soluble salts content as a result of applied organic manure. Data in Table (7) indicated that the soil bulk density was improved as a result of application organic manure. The value of bulk density was decreased from 1.52 to $1.33\left(\mathrm{Mg} \mathrm{m}^{-3}\right)$ at addition Biogas manure in the first year. Effect of organic fertilizers application for their influences on decreasing Soil bulk density can be arranged in the ascending order as follows: Biogas manure < Farmyard manure < Town refuse < Cont. Moreover, the same trend was observed after the second year and bio-fertilizer in both seasons. Biogas manure application was the most effective in decreasing Soil bulk density compared to any other manure and untreated soil. These results may be attributed to the decomposition amendments which enhance aggregation process and consequently increase apparent soil bulk density volume and decrease soil bulk density (Abd El-Hamid, 2011).

Table (7): Effect of organic fertilizer and biofertilzer on some physical properties in sandy soil in the first and secand year.

\begin{tabular}{|c|c|c|c|c|c|c|c|c|c|}
\hline \multirow[t]{3}{*}{ Organic fertilizer } & \multicolumn{9}{|c|}{$1^{\text {st }}$ year } \\
\hline & \multicolumn{3}{|c|}{ Without } & \multicolumn{3}{|c|}{ EM } & \multicolumn{3}{|c|}{$\begin{array}{l}\text { Compomax N- } \\
\text { fixers (CoM) }\end{array}$} \\
\hline & B.D. & T.P & H.C. & B.D. & T.P & H.C. & B.D. & T.P. & H.C. \\
\hline Cont.(without) & 1.52 & 42.0 & 47.2 & 1,52 & 42.04 & 47.1 & 1.52 & 42.05 & 47.2 \\
\hline Town refuse & 1.45 & 50.8 & 43.4 & 1.44 & 50.97 & 43.3 & 1.45 & 50.98 & 43.2 \\
\hline Biogas manure & 1.33 & 51.6 & 23.9 & 1.32 & 51.19 & 23.7 & 1.33 & 51.21 & 23.7 \\
\hline Farmyard manure & 1.40 & 51.3 & 30.6 & 1.38 & 51.29 & 30.5 & 1.38 & 51.32 & 30.6 \\
\hline \multicolumn{10}{|c|}{$2^{\text {nd }}$ year } \\
\hline Cont.(without) & 1.5 & 42.12 & 45.2 & 1.5 & 42.53 & 45.15 & 1.51 & 42.51 & 45.2 \\
\hline Town refuse & 1.34 & 51.5 & 37.7 & 1.33 & 51.83 & 37.4 & 1.33 & 51.73 & 37.4 \\
\hline Biogas manure & 1.28 & 52.9 & 20.5 & 1.29 & 52.33 & 20.7 & 1.28 & 52.43 & 20.8 \\
\hline Farmyard manure & 1.31 & 51.3 & 27.8 & 1.30 & 51.15 & 27.1 & 1.30 & 51.34 & 27.0 \\
\hline
\end{tabular}


These results are in agreement with those obtained by Chang et al. (1983) and Giusquiani et al. (1995) who found that bulk density was reduced by municipal sludge compost and urban waste compost respectively. As well as Zebarth et al. (1999) applied six different organic amendments including biosolids and food waste compost and found that all the materials reduced bulk density.

\section{b) Hydraulic conductivity:}

Distinct on distinguished characteristics of rapidly permeable sandy soil occurred due to low contents of organc matter and increase hydraulic conductivity The hydraulic conductivity measurement provides an indication of relative water transmission rate of the soil and depends on many factors, especially the volume of drainable pores. Data in Table (7) showed that the values of hydraulic conductivity, decreased as a result of applied organic manure. The hydraulic conductivity were decreased from $47.2 \mathrm{~cm} \mathrm{~h}^{-}$ ${ }^{1}$ in the untreated soil (control) to $23.9 \mathrm{~cm} \mathrm{~h}^{-1}$ at addition biogas manure. The data in Table (7) reveal that the biogas manure most effect in decreasing hydraulic conductivity compared to other manure and untreated soil. Effect of organic fertilizers application for their influences on decreasing hydraulic conductivity can be arranged in the decending order as follows:, Cont. > Town refuse > Farmyard manure > Biogas manure. Moreover, the same trend was observed after the second year and biofertilizer in both seasons. This could be attributed to the decreased bulk density values and the rapid decomposition of organic fertilizer and increasing organic carbon that enhance the soil aggregates, increasing the micro pores and decreasing the macro pores consequently improving physical soil properties (Mansour, 2012).

\section{c) Total porosity}

Data presented in Table (7) declared the effect of organic fertilizer (i;e FYM, biogas and town refuse) combined with bio-fertilizer (effective microorganism [EM] and the N2 fixer Compomax [CoM]) on total porosity values of expermental sandy soil. The values of total porosity in the soil were increased due to the application of organic fertilizer individually or combination with biofertilizer compared with initial value and other manure. Effect of organic fertilizers application for their influences on increasing total porosity and decreasing hydraulic conductivity can be arranged in the acending order as follows:, Cont. < Town refuse < Farmyard manure < Biogas manure. Moreover, the same trend was observed after the second year and biofertilizer in both seasons. These results may be attributed to the effect decomposition of organic fertilizer which encourage flocculation of soil particles leading to the formation of aggregates and in turn the decrease of the bulk density and increase total porosity. Moreover, the same trend was observed after the second year. Data indicated that the mean values of total porsoty were higher than that those of the second season.

\section{d) Pore size distribution}

Data in presented in Tables (8 and 9) show that mean values of pore size distribution of sandy soil after first season (bean) as affected by different improvement processes, as a result of adding organic fertilizer, either individually or in combination with biofertilzer. The obtained data indicated that the fine pores (FCP) was progressively increased by about three-fold with application any organic fertilizer as compared with control. Water holding pores (WHP) and slowly drainable pores (SDP) were also highly affected by adding any organic fertilizer, which significantly increased with application of any organic fertilizer. On the other side, data also revealed that quickly drainable pores (QDP) were decreased with application any organic fertilizer. Moreover, the same trend were 
also observed after the second year. These results may be attributed to the improvement of soil physical properties as a result of adding any organic fertilizer,either individually or in combination with biofertilizer. These results agree with Mansour (2002), who reported that the positive effect of sugar lime could be that such material serve as cementing agents. As the microbial decay of organic materials produces polymers (such as (Polysccharides and polynuorides) capable for binding soil aggregates and may a contribution on increasing soil porosity.

Table (8): Effect of organic fertilizer and biofertilzer on some physical properties in sandy soil in the first and secand year.

\begin{tabular}{|c|c|c|c|c|c|c|c|c|c|c|c|c|}
\hline \multirow{3}{*}{$\begin{array}{l}\text { Organic } \\
\text { fertilizer }\end{array}$} & \multicolumn{12}{|c|}{$1^{\text {st }}$ year } \\
\hline & \multicolumn{4}{|c|}{ Without } & \multicolumn{4}{|c|}{ EM } & \multicolumn{4}{|c|}{$\begin{array}{c}\text { Compomax N-fixers } \\
\text { (CoM) }\end{array}$} \\
\hline & Q.D.P. & S.D.P. & W.H.P. & F.C.P. & Q.D.P. & S.D.P. & W.H.P. & F.C.P. & Q.D.P. & S.D.P. & W.H.P. & F.C.P. \\
\hline Cont.(without) & 31.6 & 5.84 & 3.21 & 1.39 & 31.5 & 6.04 & 3.15 & 1.35 & 31.5 & 6.06 & 3.13 & 1.36 \\
\hline Town refuse & 27.8 & 11.9 & 6.72 & 4.38 & 27.7 & 12.1 & 6.75 & 4.42 & 27.4 & 12.2 & 6.6 & 4.78 \\
\hline Biogas manure & 26.2 & 12.2 & 7.39 & 4.81 & 26.3 & 12.4 & 7.55 & 4.94 & 26.3 & 12.3 & 7.6 & 5.01 \\
\hline \begin{tabular}{|l|} 
Farmyard \\
manure
\end{tabular} & 27.2 & 12.8 & 7.88 & 3.42 & 27.3 & 13.1 & 7.27 & 3.62 & 27.3 & 12.9 & 7.49 & 3.63 \\
\hline \multicolumn{13}{|c|}{$2^{\text {nd }}$ year } \\
\hline Cont.(without ) & 31.4 & 6.02 & 3.28 & 1.42 & 31.4 & 6.36 & 3.30 & 1.47 & 31.4 & 7.34 & 3.33 & 1.44 \\
\hline Town refuse & 18.4 & 18.0 & 8.60 & 6.5 & 18.5 & 18.2 & 8.63 & 6.5 & 18.5 & 18.1 & 8.73 & 6.4 \\
\hline Biogas manure & 17.9 & 19.9 & 9.65 & 5.45 & 17.4 & 20.2 & 9.4 & 5.33 & 17.4 & 20.2 & 9.0 & 5.83 \\
\hline \begin{tabular}{|l|}
$\begin{array}{l}\text { Farmyard } \\
\text { manure }\end{array}$ \\
\end{tabular} & 16.3 & 20.8 & 9.28 & 4.92 & 16.1 & 20.7 & 9.6 & 4.75 & 16.2 & 20.4 & 9.9 & 4.84 \\
\hline
\end{tabular}

Without: no biofertilizer, EM: Effective microorganism, CoM: N fixer Compo max

Table (9): Effect of organic fertilizer and biofertilzer on some physical properties in sandy soil in the first and secand year.

\begin{tabular}{|l|c|c|c|c|c|c|c|c|c|}
\hline \multirow{2}{*}{ Organic fertilizer } & \multicolumn{9}{|c|}{$1^{\text {st }}$ year } \\
\cline { 2 - 11 } & \multicolumn{3}{|c|}{ Without } & \multicolumn{3}{c|}{ EM } & \multicolumn{3}{c|}{$\begin{array}{c}\text { Compomax N-fixers } \\
\text { (CoM) }\end{array}$} \\
\cline { 2 - 11 } & F.C. & W.P. & A.W. & F.C. & W.P. & A.W. & F.C. & W.P. & A.W. \\
\hline Cont.(without) & 10.4 & 4.09 & 6.11 & 10.2 & 4.10 & 6.18 & 10.3 & 4.11 & 6.2 \\
\hline Town refuse & 12.9 & 5.04 & 7.3 & 13.3 & 5.09 & 7.31 & 13.1 & 5.10 & 6.76 \\
\hline Biogas manure & 14.2 & 5.38 & 6.24 & 14.2 & 5.42 & 6.28 & 13.9 & 5.41 & 6.6 \\
\hline Farmyard manure & 14.8 & 5.85 & 6.6 & 14.9 & 5.79 & 6.63 & 14.9 & 5.80 & 6.8 \\
\hline \multicolumn{9}{|c|}{$\mathbf{2}^{\text {nd }}$ year } \\
\hline Cont.(without) & 10.5 & 4.21 & 6.32 & 10.5 & 4.21 & 6.33 & 10.5 & 4.21 & 6.32 \\
\hline Town refuse & 13.1 & 5.21 & 7.5 & 13.1 & 5.22 & 7.52 & 13.2 & 5.23 & 7.53 \\
\hline Biogas manure & 14.2 & 5.94 & 7.9 & 14.2 & 6.03 & 8.1 & 14.2 & 8.12 & 8.12 \\
\hline Farmyard manure & 15.1 & 6.21 & 7.8 & 15.4 & 6.23 & 8.0 & 15.5 & 8.11 & 8.11 \\
\hline
\end{tabular}

Without: no biofertilizer, EM: Effective microorganism, CoM: $\mathrm{N}$ fixer Compo max 


\section{e) Soil moisture retention and Water holding capacity:}

Data in Table (9) reveal that soil moisture content at field capacity and wilting point were significant increased with application of organic minure either individually or in combination with bio-fertilizer. This result may be attributed to increase the total prosity, fine capillary pores and decrease the volume of wide pores, as a result of application of any organic manure. While the available water is significantly increased.This result may be due to the effect of organic manure increasing the micro pores and decreasing the macro pores. Similar results were obtained by Mansour (2007) and Mariano et al., (2009).

\section{Yield of Faba bean}

The determined yield components of faba bean crop such as 100 seed weight, seed and foliage yields significantly influenced by manure application practices (Table 10). Application of farmyard manure (FYM) significantly influenced the yield components of faba bean compared to mineral fertilizer, town refuse and biogas manure. The treatment of $\mathrm{FYM}+\mathrm{EM}$ application significantly increased the 100-seed weight $(88.7 \mathrm{~g})$, seed yield $\left(1620 \mathrm{~kg} \mathrm{fed}^{-1}\right)$ and foliage yield (4229 $\left.\mathrm{kg} \mathrm{fed}^{-1}\right)$, over the treatment receiving FYM alone and the othere. Such favorable effects on yield and yield components could be attributed to the stimulation effect of NPK on number and weight of nodules and nitrogen metabolism, which in turn reflected positively on faba bean yield attributes. These increases in yield and its components as a result of application of the farmyard manure over Biogas and town refuse application may be attributed to higher content of macronutrients, which might enhance the activity of photosynthesis and protein synthesis in the leaves. This in turn encourages photosynthetic process apparatus. The elemental composition of the organic manure applied especially their content of $\mathrm{N}, \mathrm{P}, \mathrm{K}, \mathrm{Fe}, \mathrm{Mn}, \mathrm{Zn}$ and Cu may account for such finding. Beneficial microorganisms in bio-fertilizers accelerate and improve plant growth and protect plants from pests and diseases (El-yazeid et al., 2007).

\section{Yield of Residual crop (Maize)}

With respect to the residual effect of applied manures on maize yield and its components (Table 10) application of organic manure had distinctly influenced yield components of maize. The highest values of 100 -grain weight $(38.0 \mathrm{~g})$, grain $\left(6708 \mathrm{~kg} \mathrm{fed}^{-1}\right)$ and stover yield $(5180 \mathrm{~kg}$ $\mathrm{fed}^{-1}$ ) were recorded in biogas manure treatment compared to FYM followed by town refuse, respectively. The lowest 100 grain weight, grain and stover yield recorded in the treatment receiving town refuse and control. This might be due to higher yield components that are directly responsible for grain yield that appeared to have been determined by physiological characters, both during vegetative and reproductive phase of the crop growth. Mando et al. (2005) also found that soil organic matter and crop performance were better maintained by using organic materials with a low $\mathrm{C} / \mathrm{N}$ ratio (manure) than those with a high $\mathrm{C} / \mathrm{N}$ ratio (straw).

The treatment of biogas manure + EM significantly increased 100-grain weight (38 g), grain yield $\left(6708 \mathrm{~kg} \mathrm{fed}^{-1}\right)$ and $(5180 \mathrm{~kg}$ $\left.\mathrm{fed}^{-1}\right)$ and they were significantly surpassed superior over the other treatments. The nutrient assimilation of biogas manure in plants and grains, applied singly or in combination with EM may produce more available nutrients in soil resulted in an increase of maize grain yield. Foliar biofertilization by EM and CoM is readily absorbed by the leaves and not lost through fixation, decomposition or leaching.

Higher effect of biogas manure than the other two organic manure (farmyard manure and town refuse ) may be due the narrowest $\mathrm{C} / \mathrm{N}$ ratio and its higher content of $\mathrm{N}, \mathrm{P}$ and $\mathrm{Fe}$ and $\mathrm{Zn}$ (Table 2), Similar results were obtained by Nasef (2004) who stated that the positive effect of pigeon manure extract on wheat yield and its components surpassed the organic manure extracts of biogas and chicken manure. 
Table 10: Effect of organic fertilizer and biofertilzer on yield parameters in sandy soil in the first and secand year.

\begin{tabular}{|c|c|c|c|c|c|c|c|c|c|c|c|c|}
\hline \multirow{3}{*}{ Organic fertilizer } & \multicolumn{12}{|c|}{$1^{\text {st }}$ year } \\
\hline & \multicolumn{4}{|c|}{100 seed weight $(\mathrm{g})$ of bean } & \multicolumn{4}{|c|}{ Seed yield $(\mathrm{kg} / \mathrm{fed})$ of bean } & \multicolumn{4}{|c|}{ Foliage yield $(\mathrm{kg} / \mathrm{fed})$ of bean } \\
\hline & Without & EM & CoM & Mean & Without & EM & CoM & Mean & Without & EM & CoM & Mean \\
\hline Con.( Without ) & 54.1 & 67.4 & 56.4 & 59.3 & 510.1 & 763.3 & 603.4 & 625.6 & 611 & 1432 & 1108 & 1050 \\
\hline Town refuse & 78.6 & 86.9 & 84.8 & 83.4 & 577 & 1313 & 1003 & 965 & 700 & 2298 & 1525 & 1508 \\
\hline Biogas manure & 83.1 & 88.7 & 86.0 & 86.0 & 923 & 1620 & 1212 & 1252 & 1309 & 4229 & 1848 & 2462 \\
\hline Farmyard manure & 81.4 & 87.7 & 85.8 & 84.9 & 775 & 1391 & 1068 & 1078 & 885 & 2821 & 1681 & 1796 \\
\hline Mean & 24.3 & 82.6 & 78.2 & & 696.3 & 1271 & 972 & & 876 & 2695 & 1541 & \\
\hline \multirow{3}{*}{ LSD (5 \%) } & \multirow{2}{*}{\multicolumn{2}{|c|}{ Biofertilzer }} & \multicolumn{2}{|l|}{0.89} & \multicolumn{4}{|c|}{77.94} & \multicolumn{4}{|c|}{394.4} \\
\hline & & & \multicolumn{2}{|l|}{0.50} & \multicolumn{4}{|c|}{54.33} & \multicolumn{4}{|c|}{309.1} \\
\hline & \multicolumn{2}{|l|}{ Interaction } & \multicolumn{2}{|l|}{0.82} & \multicolumn{4}{|c|}{ NS } & \multicolumn{4}{|c|}{507.11} \\
\hline \multirow{3}{*}{ Organic fertilizer } & \multicolumn{12}{|c|}{$2^{\text {nd }}$ year } \\
\hline & \multicolumn{4}{|c|}{100 Grain weight $(\mathrm{g})$ of maize } & \multicolumn{4}{|c|}{ Grain yield $(\mathrm{kg} / \mathrm{fed})$ of maize } & \multicolumn{4}{|c|}{ Stover $(\mathrm{kg} / \mathrm{fed})$ of maize } \\
\hline & Without & EM & CoM & Mean & Without & EM & CoM & Mean & Without & EM & CoM & Mean \\
\hline Con.( Without ) & 16.3 & 23.4 & 18.7 & 19.5 & 1612 & 2306 & 2877 & 2265 & 2145 & 3380 & 2606 & 2710 \\
\hline Town refuse & 27.6 & 36.2 & 33.4 & 32.4 & 1850 & 2717 & 2900 & 2489 & 2742 & 4258 & 3617 & 3539 \\
\hline Biogas manure & 32.4 & 38.0 & 35.3 & 35.2 & 2725 & 3708 & 3308 & 2247 & 3442 & 5180 & 3920 & 4181 \\
\hline Farmyard manure & 30.3 & 37.0 & 34.6 & 34.0 & 2492 & 3242 & 3040 & 2925 & 3185 & 4475 & 3850 & 3837 \\
\hline Mean & 26.7 & 33.7 & 30.5 & & 2169 & 2243 & 3031 & & 2879 & 4323 & 3498 & \\
\hline \multirow{3}{*}{ LSD (5 \%) } & \multirow{2}{*}{\multicolumn{2}{|c|}{$\begin{array}{c}\text { Organic } \\
\text { Biofertilzer }\end{array}$}} & \multicolumn{2}{|l|}{0.51} & \multicolumn{4}{|c|}{231.0} & \multicolumn{4}{|c|}{109.2} \\
\hline & & & \multicolumn{2}{|l|}{0.29} & \multicolumn{4}{|c|}{205.1} & \multicolumn{4}{|c|}{87.7} \\
\hline & \multicolumn{2}{|l|}{ Interaction } & \multicolumn{2}{|l|}{0.47} & & NS & & & & 143.8 & & \\
\hline
\end{tabular}

Without: no biofertilizer, EM: Effective microorganism, CoM: $\mathrm{N}$ fixer Compo max

\section{CONCLUSION}

Could be concluded that application of any orginc manure improved the physical and chemical properties of the expermental soil due to increasing total porosity (T.P), fine capillary pores (FCP), soil moisture contents at field capacity (F.C), wilting point (W.P), available water (A.W). ECe, O.M, and available $\mathrm{N}, \mathrm{P}$ and $\mathrm{K}$. On the contrary, decrease in $\mathrm{pH}$, bulk density (B.D), hydraulic conductivity (H.C) and quickly drainable pores as compared with the control.Furthermore, application of biogas manure combined with EM recorded the highest yield parameters. The likewise,an increase in organic matter was occurred with the used organic fertilizers. efficient use of fertilizers supplements the nutrient-supplying capacity increased of soil organic content. Manures have the potential to improve crop nutrition. They may be particularly beneficial in terms of minor elements.

\section{REFERENCES}

Abd El-Hamid, Azza, R., S.F. Mansour, T.A. EL-Maghraby and M.A.A. Barky (2011). Competency of some soil amendments used for improvement of extreme salinity of Shall El-Tina, soil J. Soil Sci. and Agric. Eng. Mansoura Univ., 2: 649-667.

Barzegar, A.R., P.N. Nelson, J.M. Oades and P. Rengasamy (1997). Organic 
matter, sodicity, and clay type:Influence on soil aggregation. Soil Sci. Soc. Am. J., 61: 1131-1137.

Bevacqua, R.F. and V.J. Mellano (1994). Cumulative effects of sludge compost on crop yield and soil properties. Communications in Soil Science and Plant Analysis 24: 395-406.

Celik, I., I. Ortas and S. Kilic (2004). Effects of compost, mycorrhiza, manure and fertilizer on some physical properties of a Chromoxerert soil. Soil Tillage Res., 78: 59- 67.

Chang, A.C., A.L. Page and J.E. Warneke (1983). Soil conditioning effect of municipal sludge compost. Journal of Environmental Engineering 109: 574583.

Chen, Jen-Hshuan (2006). The combined use of chemical, organic fertilizers and/or biofertilizer for crop growth and soil fertility. Technical Bulletin 174, Food \& Fertilizer Technology Center. Taipei, ROC.

Cottenie, A., M. Sverloo, L. Kiekens, G. Velghe and R. Comerlynck (1982). Chemical and analysis of plants and soils State Univ., Ghent Belgium.

De-Leenheer, L. and M. De-Boodt (1965). Soil Physics. "International Training Center for Post Gradual Soil Scientist" Ghent, Belgium.

El-Yazeid, A. A., H. A. Abou-Aly, M. A. Mady and S. A. M. Moussa (2007). Enhancing growth, productivity and quality of squash plants using phosphate dissolving microorganisms (biophosphor) combined with boron foliar spray. Res. J. Agric. Biol. Sci., 3: 274-286.

Gee, G.W. and. J. W. Bauder (1986). Particle size analysis. In "Methods of soil analysis". Part 1, PP. 383-409., Klute, A.,(Ed.), Amer. Soc. Agron., Madison, WI, USA.

Ghafoor, A., G. Murtaza and M. Qadir (2001). Gypsum: an economical amendment for amelioration of salinesodic waters and soils for improving crop yield. In: National Workshop on
Agricultural Use of Gypsum. LRRI, NARC, PARC, Islamabad, Pakistan.

Giusquiani, P.L., M. Pagliai, G. Giglotti, D. Buisinelli and A. Beneti (1995). Urban waste compost: Effects on physical, chemical and biochemical soil properties. Journal of Environmental Quality 24: 175182.

Haynes, R. and R. Naidu (1998). Influence of lime, fertilizer and manure applications on soil organic matter content and soil physical conditions: A review. Nutr. Cycl. Agroecosys. 51: 123-137.

Jensen, T., A. Johnston, D. Franezen and J. Stika (2015). Fertilizer BMPs- Suggested practices for semiarid North Dakota. Fertilizer Best Management Practices. International Plant Nutrition Institute

Kato, S., H. L. XU, M. Fujita, K. Yamada, K. Karose and $\mathrm{H}$. Umemura (1999). Effect of organic fertilization and EM application on growth pattern, nutrient uptake and grain yield of sweet corn. 6th International Conference on Kyusei Nature farming Pretoria, Pretoria, South Africa, 28-31 Octotber.

Khosro, M. and S. Yousef (2012). Bacterial bio-fertilizers for sustainable crop production: a review. J. Agric. Biolog. Sci., 7: 307-316.

Klute, A. and C. Dirksen (1986). Hydraulic Conductivity and Diffusivity: Laboratory Methods. In:" Methods of Soil Analyses". Part 1, PP., 687-734, Klute A. (Ed.), Amer. Soc. of Agron. Madison, WI, USA.

Khafagy, E.E.E., E.G. Abo-Elela, E.F. Ramadan and A.M. AbdEl-Fattah (2015). Influence of different types and rates of organic fertilizers application for improv1ng some properties of salt affected soils and maize productivity . Egypt. j. of Appl. Sci.: 30(9).

Mando, A., M. Bonzi, M. C. S. Wopereis, F. Lompo and L. Stroosnijder (2005). Longterm effects of mineral and organic fertilization on soil organic matter fractions and sorghum yield under Sudano-Sahelian conditions. Soil Use Manag., 21: 396-401. 
Mansour, S.F. (2002). Improvement of soil structure in some soils of Egypt. Ph.D. Thesis Fac. Of Agric. Cairo Univ., Egypt.

Mansour, S.F. (2007). Improving some physical properties of calcareous soils by using diluted sulfuric acid and organic manure. Minufiya. J. Agric. Res., 32: 553 -562 .

Mansour, S.F. (2012). Comparative effect of some industrial wastes as soil conditioners on some physiochemical hydro physical soil properties and maize productivity. Minufiya J. Agric. Res. 2:387-396.

McConnell, D.B., A. Shiralipour and W.H. Smith (1993). Compost Application Improves Soil Properties. Biocycle 34: 61-63.

Mariano, A.P., H.R. Sergio, F.A. Dejanira and M.B. Bonito (2009). The use of vinasse as an amendment to exist bioremediation of soil and ground water contaminated with diesel oil. Brazilian Archives of biology and technology, 4: 1043-1055.

Mokolabate, M.S. and R.J. Haynes (2002). Comparative liming effect of four organic residues applied to an acid soil. Biology and Fertility of Soils 35, 79-85.

Mosa, W.F.A.E.G., L.S. Paszt, M. Frąc and P. Trzciński (2015). The Role of Biofertilization in Improving Apple Productivity-A Review. Advances in Microbiology, 5: 21-27. http://dx.doi.org/10.4236/aim.2015.51003

Nasef, M. A. (2004). Comparative study on effect of foliar application of Urea and some organic manure extracts on wheat yield and its components. Annals Agric. Sci., Moshtohor. 42: 861-870.

Page, A.I., R.H. Miller and D.R. Keeney (Eds.) (1982). Methods of Soil Analysis. Part 2: Chemical and Microbiological Properties. 2 nd Edition, Amer. Soc. of Agron. Madison, Wisconsin, U.S.A.

Pandey,P., R. Kunnar and P. Mishra (2011). Integrated approach for the management of Sclerotinia- sclerotiorum, causing stem rot of chickpea. Indian Phytopathology, 64(1):37-40.

Prabu, K., G. and K. B. Uthaya (2006). Use of organics for crop production under rainfed situation - A review. Agric. Rev., 27: 208 -215.

Rebecca, B. (2004). "Soil Survey Methods Manual". Soil Survey Investigations Report No. 42, Natural Resources Conservation Services, USDA, USA.

Rokhzadi, A., A. Asgharzadeh, F. Darvish, G. Nourmohammadi and E. Majidi (2008). Influence of plant growthpromoting rhizobacteria on dry matter accumulation and yield of chickpea (Cicer arietinum L.) under field condition. Am-Euras. J. Agric. Environ. Sci., 3: 253257.

Sharma, A. R. and B. N. Mittra (1991). Effect of different rates of application of organic and nitrogen fertilizers in a rice-based cropping system. J. Agric. Sci., 117: 313318.

Sndecor, G. W. and W. G. Cochran (1989). "Statistical Methods" 8th Ed. lowa State Univ., Press Amer. lowa U.S.A., 325-330.

Tiwari, A., A. K. Dwivedi and P. R. Dikshit (2002). Longterm influence of organic and inorganic fertilization on soil fertility and productivity of soybean-wheat system in a yield components of sweet corn (Zea mays L.), under semiarid environment. Not Bot Hort Agrobot Cluj., 37: 105-111.

Vomocil, J.A. (1965). Methods of Soil Analyses. Part 1 Edited by Klute, As Monograph No. 9, Madison, Wisconsin.

Youssef, M. A. (2011). Synergistic impact of effective microorganisms and organic manures on growth and yield of wheat and marjoram plants. Ph. D. Thesis, Fac. Agric., Assiut Univ., Assiut, Egypt.

Zebarth, B.J., G.H. Nelen, E. Hogue and D. Neilsen (1999). Influence of organic waste amendments on selected soil physical and chemical properties. Can. J. Soil Sci., 79: 501-504. 
الاستخدام الأفضل للأسمدة الحيوية العضوية لتحسين بعض الخواص الطبيعية للاراضى الرملية وزيادة إنتاجية الفول البلدي والذرة

صبحي فهي منصور ، عبد العزيز محمد محمد رجب ، عصام جودة أبو العلا ، عصام فوقى رمضان

معهز بحوث الأراضي والمياه والبيئة - الجيزة - مصر

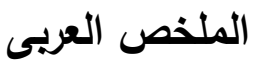

أقيمت تجربتين حقليتين لتقييم تأثير إضافة الاسمده العضوية بالتداخل مع الأسمدة الحيوية على تحسين بعض

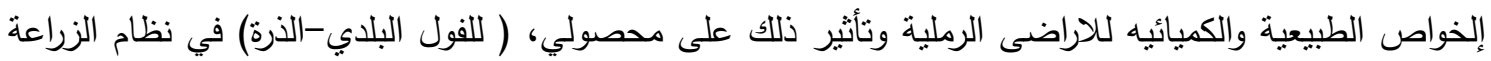
المتسلسل تحت نظام الري بالرش.

تم تصميم التجربة إحصائياً بنظام القطع المنشقة في ثلاث مكررات لكل معاملة، وكانت المعاملات كالآتي:معاملة المقارنة، (ألزراعه التقليدية باستخدام الأسمدة الكيماوية)، معاملة الأسمدة العضوية، لتهبة (الأسمدة البلدية-

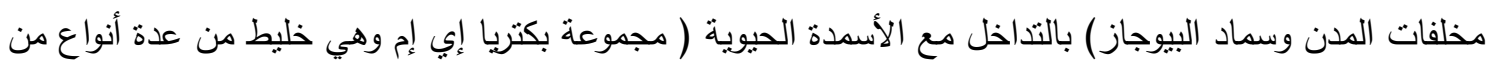
الكائنات الحية الدقيقة) ومخلوط بكتريا مثثبنة للنيتروجين). - أدت إضافة الأسمدة العضوية إلى تحسن في بعض الخواص الطبيعية و الكميائيه للاراضى الرملية فقد ذادت قيم

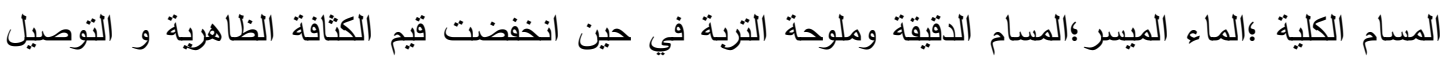

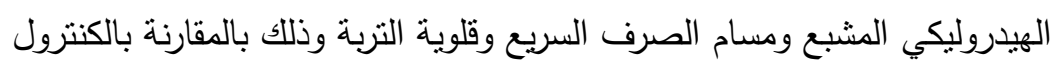

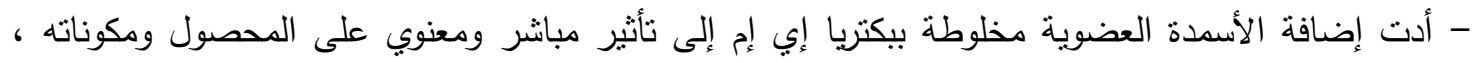

$$
\text { (محصول البذور، وزن آل } 100 \text { بذرة، المحصول الخضري لنباتات الفول.). }
$$

- أظهرت نتائج نظام الزراعة المتسلسل استجابة محصول الذرة ، وكذلك صفات المحصول، وزن آل 100 حبة، لاستخدام الأسمدة العضوية، وحققت معاملة استخدام الأسمدة العضوية بالتداخل مع الأسمدة الحيوية والمعدنية أفضل محصول الذرة. - أدى استخدام الأسمدة العضوية والحيوية إلى تحسن مستوى المادة العضوية بالتربة، والتي بدورها أدت إلى زيادة المحصول. - أظهر استخدام الأسمدة العضوية إن هناك اختلافات معنوية بين المعاملات خاصة فيما يتعلق بتيسر عناصر النيتزوجين والفسفور والبوتاسيوم. - سجل استخدام سماد البيوجاز بالتداخل مع بكتريا إي إم أعلى تيسر لعناصر النيتروجين والفسفور والبوتاسيوم

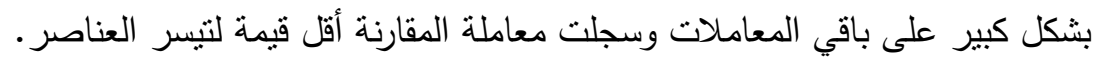


